\title{
Organic and nutrient removal during start-up period for domestic sewage treatment by an A/O mixed carrier system
}

\author{
Wei Liao, Hui-qiang Li, and Ping Yang \\ College of Architecture and Environment, Sichuan University, Chengdu 610065 Chengdu, China.
}

\begin{abstract}
This study combined biofilm method and A/O process reasonably to form the biological treatment system. This experiment focused on the performance of the system for domestic sewage according to the determination of $\mathrm{COD}_{\mathrm{Cr}}$, ammonia nitrogen, total nitrogen, and total phosphorus. The A/O-mixed carrier system had a good removal effect on organic pollutants for simulated domestic sewage. At the start-up period, the average removal rates of $\mathrm{COD}_{\mathrm{Cr}}$, ammonia nitrogen and total nitrogen were $92 \%, 90 \%$ and $55 \%$, respectively. But the removal effect of total phosphorus was not ideal.
\end{abstract}

\section{Introduction}

The rapid development of social economy and urbanization construction has steadily advanced, but it has also made a series of problems such as insufficient water resources and serious water pollution, which is mainly due to the complexity of sewage. The organic matter has caused serious pollution to the water environment, and a large amount of nutrients such as nitrogen and phosphorus enter the water body, making the water body eutrophic $[1,2]$. Stricter standards of water pollutant discharge have been issued by various local government, which put forward higher requirements for municipal sewage treatment plants. The traditional sewage treatment processes are difficult to meet the current demand. At present, China's municipal sewage treatment plants mainly adopt A/O-based treatment process due to it is stable, reliable, small footprint, fully denitrification and relatively easy to control. However, its removal effect on nutrient elements in sewage is not ideal. Since the mixed liquid comes from the aeration zone, which contains partially dissolved oxygen. The denitrification effect is low, and the total nitrogen removal efficiency $(50-70 \%)$ is difficult to increase [3]. Therefore, the building and modification of the sewage treatment plant is imperative. A common method for improving the quality of sewage treatment plants is to use a new secondary treatment process for wastewater treatment to obtain better water quality [4]. Membrane Bioreactor (MBR) [5], Fluidized Bed Biological Reactor (FBBR) [6], Moving Bed Biofilm Reactor (MBBR) [7] and other technologies are used to replace the traditional process, so as to efficiently remove organic matter and simultaneously remove nitrogen and phosphorus.

Moving Bed Biofilm Reactor (MBBR) has been developed as one of the most attractive hydraulic systems, which combines the characteristics of membrane technology and activated sludge technology. MBBR is promoted mainly because more biomass can be sustained in the reactor. The higher and more stable removal effect may be achieved through the use of various nature and type of the carrier elements [8]. Kaindl et al. [9] added MBBR as a pretreatment in the front stage of the conventional activated sludge process, and combined with ozone at the end to upgrade the domestic sewage plant. The advanced treatment effectively improved the removal effect on COD at a simple operation condition.

This study combined biofilm method and $\mathrm{A} / \mathrm{O}$ process reasonably to form the biological treatment system, which takes advantage of various fillers to improve the decontamination efficiency of the system. The performance of the system for domestic sewage according to the determination of $\mathrm{COD}_{\mathrm{Cr}}$, ammonia nitrogen, total nitrogen was investigated.

\section{Material and methods}

The reactor was made of plexiglass, which was combined with two zones: anoxic zone and aerobic zone. The anoxic zone was $10 * 10 * 30 \mathrm{~cm}$ with an effective volume of $3 \mathrm{~L}$. The bio-band was fixed at the upper end of the anoxic reactor as a microbial carrier, the filler was fully mixed with the influent water by mechanical stirring at the bottom. The aerobic zone was $30 * 10 * 40 \mathrm{~cm}$, which was combined with aeration zone and sedimentation zone. The effective volume of aeration zone and sedimentation zone were 7.5 and $3.68 \mathrm{~L}$, respectively.

In this study, the $\mathrm{A} / \mathrm{O}$-mixed carrier system was used to treat the simulated domestic sewage. The experiment used artificial water distribution, with glucose as the main carbon source and ammonium chloride provided ammonia nitrogen and total nitrogen, potassium dihydrogen phosphate provided total phosphorus. The nitrogen and phosphorus loads were gradually increased during the start-up period. The concentration ratio of $\mathrm{COD}_{\mathrm{Cr}}: \mathrm{N}: \mathrm{P}$ in the influent was finally controlled to $350: 40: 5\left(\mathrm{COD}_{\mathrm{Cr}}\right.$ concentration was $\left.350 \mathrm{mg} / \mathrm{L}\right)$.

The biofilm formation in aerobic zone used the rapid sludge discharging method. The biofilm formation in anoxic zone used a combination of aerobic pre-attachment membrane and rapid sludge discharge. The aerobic activated sludge and the influent water were poured into the reactor with a ratio of $1: 3$. The sludge and the filler were fully 
contacted. At this time, the anoxic zone and the aerobic zone were aerated separately. The aeration rates were $500 \mathrm{~mL} / \mathrm{min}$ and $1 \mathrm{~L} / \mathrm{min}$, respectively. The anoxic zone and the aerobic zone were continuously inlet water under aeration conditions $\left(\mathrm{COD}_{\mathrm{Cr}}=350 \mathrm{mg} / \mathrm{L}, \quad \mathrm{COD}_{\mathrm{Cr}}: \mathrm{N}: \mathrm{P}=350: 17.5: 3.5\right)$. After running for three days, a thin biofilm was observed on the bioband, which indicated that the aerobic pre-coating film was successful. The anoxic activated sludge and the influent water were poured into the reactor with a ratio of $1: 3$. The sludge was fully contacted with the bio-band using the mechanical agitation. After 24 hours, the sludge was discharged, and then the water was continuously injected under stirring. After continually running for three days, the $\mathrm{COD}_{\mathrm{Cr}}$ removal efficiencies in the anoxic zone and the aerobic zone reached $60 \%$ and $90 \%$, respectively. And the ammonia nitrogen removal efficiency reached $85 \%$. This indicated that the aerobic zone and the anoxic zone had formed membrane successfully.

After cultivating bio-film, the anoxic zone and the aerobic zone were connected in series to form a biological reaction system of the A/O-mixed carrier system. The influent flow rate of the system was set to $1.3125 \mathrm{~L} / \mathrm{h}$, and the total hydraulic retention time of the reactor was $8 \mathrm{~h}$. The data was measured every two days during the start-up stage. The influent nitrogen and phosphorus load was gradually increased during the start-up stage, from the initial influent $\mathrm{COD}_{\mathrm{Cr}}: \mathrm{N}: \mathrm{P}=350: 17.5: 3.5$ to $\mathrm{COD}_{\mathrm{Cr}}: \mathrm{N}: \mathrm{P}=350: 25: 5$, and finally increased to $\mathrm{COD}_{\mathrm{Cr}}: \mathrm{N}: \mathrm{P}=350: 40: 5$.

\section{Results}

The removal efficiency of $\mathrm{COD}_{\mathrm{Cr}}$ in the start-up period is shown in Fig.1. The influent $\mathrm{COD}_{\mathrm{Cr}}$ concentration was maintained at $357.27 \pm 20.73 \mathrm{mg} / \mathrm{L}$. With the increase of nitrogen and phosphorus loads, the effluent $\mathrm{COD}_{\mathrm{Cr}}$ concentration was maintained stably at $27.40 \pm 12.48 \mathrm{mg} / \mathrm{L}$, and the average $\mathrm{COD}_{\mathrm{Cr}}$ removal efficiency was $92.32 \%$. This indicated the reactor had good impact resistance. The removal efficiency of $\mathrm{COD}_{\mathrm{Cr}}$ in the anoxic zone increased gradually from $46.47 \%$ to $56.50 \%$. Correspondingly, the removal efficiency of $\mathrm{COD}_{\mathrm{Cr}}$ in the aerobic zone decreased from $78.83 \%$ to $60.44 \%$. This was due to the gradual formation of biofilm on the bio-band in the anoxic zone, and the increase in biomass led to an increase in the removal efficiency of $\mathrm{COD}_{\mathrm{Cr}}$. Although the removal rates of the anoxic zone and the aerobic zone fluctuated, they were all maintained at more than $50 \%$, indicating that the microbial growth in the anoxic zone and the aerobic reactor was good.

The removal efficiency of ammonia-nitrogen in the startup period is shown in Fig.2. The removal effect of ammonianitrogen decreased slightly. With the increase of ammonianitrogen load in the influent, the ammonia-nitrogen removal efficiency in the anoxic zone decreased from $31.45 \%$ to $9.18 \%$. This was due to the anoxic reactor acclimated a certain amount of nitrifying bacteria in the aerobic pre-coating period, and some dissolved oxygen was present in the influent and reflux. This resulted in the presence of an environment suitable for the survival of nitrifying bacteria at the bottom of the anoxic reactor. Therefore, the anoxic zone had a certain removal effect for ammonia nitrogen. After a period of running time, the dissolved oxygen in the anoxic zone was

very low, which was not suitable for the survival of nitrifying bacteria. This resulted in a decrease in the ammonia nitrogen removal efficiency in the anoxic zone and almost no removal effect for ammonia-nitrogen. The aerobic zone had a higher and more stable ammonia-nitrogen removal efficiency in the first two period, which was maintained at $85.15 \pm 11.65 \%$. The good removal effect was because the ammonia-nitrogen load was low. When the ammonia-nitrogen raised to $21.41 \pm 2.14 \mathrm{mg} / \mathrm{L}$ in the aerobic zone, the removal efficiency decreased. But then the removal effect of ammonia-nitrogen gradually recovered, indicating the reactor can withstand the load. The removal trend of ammonia nitrogen by biological reaction systems was similar to that of aerobic zones. In the first two periods, the ammonia-nitrogen removal efficiency was stable at $93.90 \pm 4.89 \%$, and the effluent ammonianitrogen concentration was lower than $1.50 \mathrm{mg} / \mathrm{L}$. When the influent ammonia-nitrogen concentration rose to $41.13 \pm 1.86$ $\mathrm{mg} / \mathrm{L}$, the removal efficiency decreased. But then it gradually recovered and the removal efficiency rose to $90.12 \pm 4.74 \%$.

The treatment effect on total nitrogen decreased with the increase of the influent nitrogen and phosphorus loads. As shown in Fig.3, with the increase of total nitrogen load, the removal efficiency of total nitrogen in the anoxic zone gradually decreased from the $31.53 \pm 6.04 \%$ to $13.75 \pm 5.55 \%$, which was due to the decrease in the proportion of nitrate and nitrite in the total nitrogen in the anoxic zone. In aerobic zone, the total nitrogen removal efficiency remained at $32.64 \pm 11.21 \%$, which was relatively stable. The removal efficiency of total nitrogen in the biological reaction system decreased from $74.14 \pm 3.51 \%$ to $55.07 \pm 11.47 \%$ with the increase of total nitrogen load. In addition, with the increase of influent total nitrogen concentration, the effluent total nitrogen concentration also increased from $4.74 \pm 0.42 \mathrm{mg} / \mathrm{L}$ to $18.38 \pm 4.18 \mathrm{mg} / \mathrm{L}$.
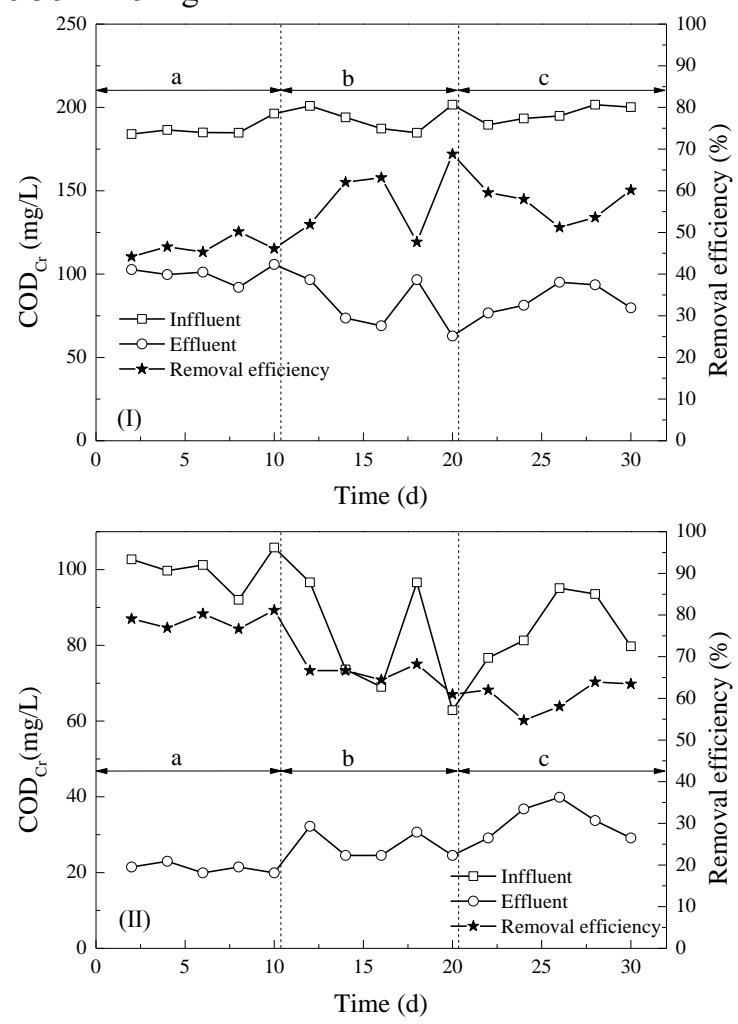


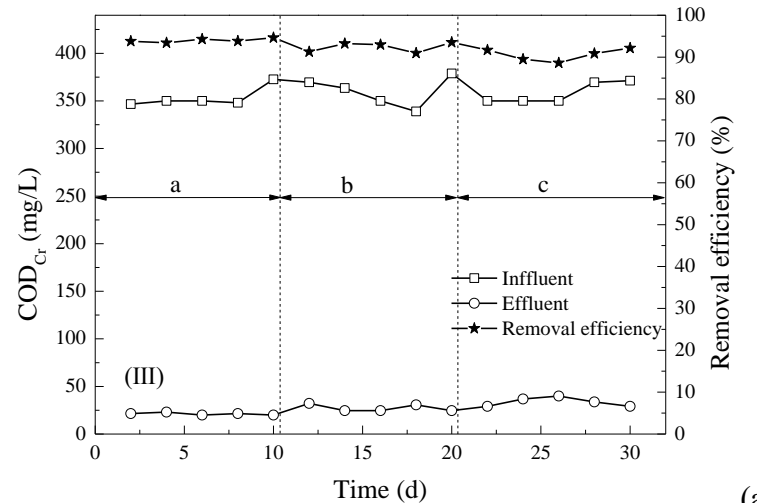

$\mathrm{COD}_{\text {Cr: }}: \mathrm{P}=350: 17.5: 3.5$; b. $\mathrm{COD}_{\mathrm{Cr}}: \mathrm{N}: \mathrm{P}=350: 25: 5$; c. $\left.\mathrm{COD}_{\mathrm{Cr}}: \mathrm{N}: \mathrm{P}=350: 40: 5\right)$

Fig.1. Performance of (I) anoxic zone, (II) aerobic zone, (III) biological treatment system for $\mathrm{COD}_{\mathrm{Cr}}$ removal.
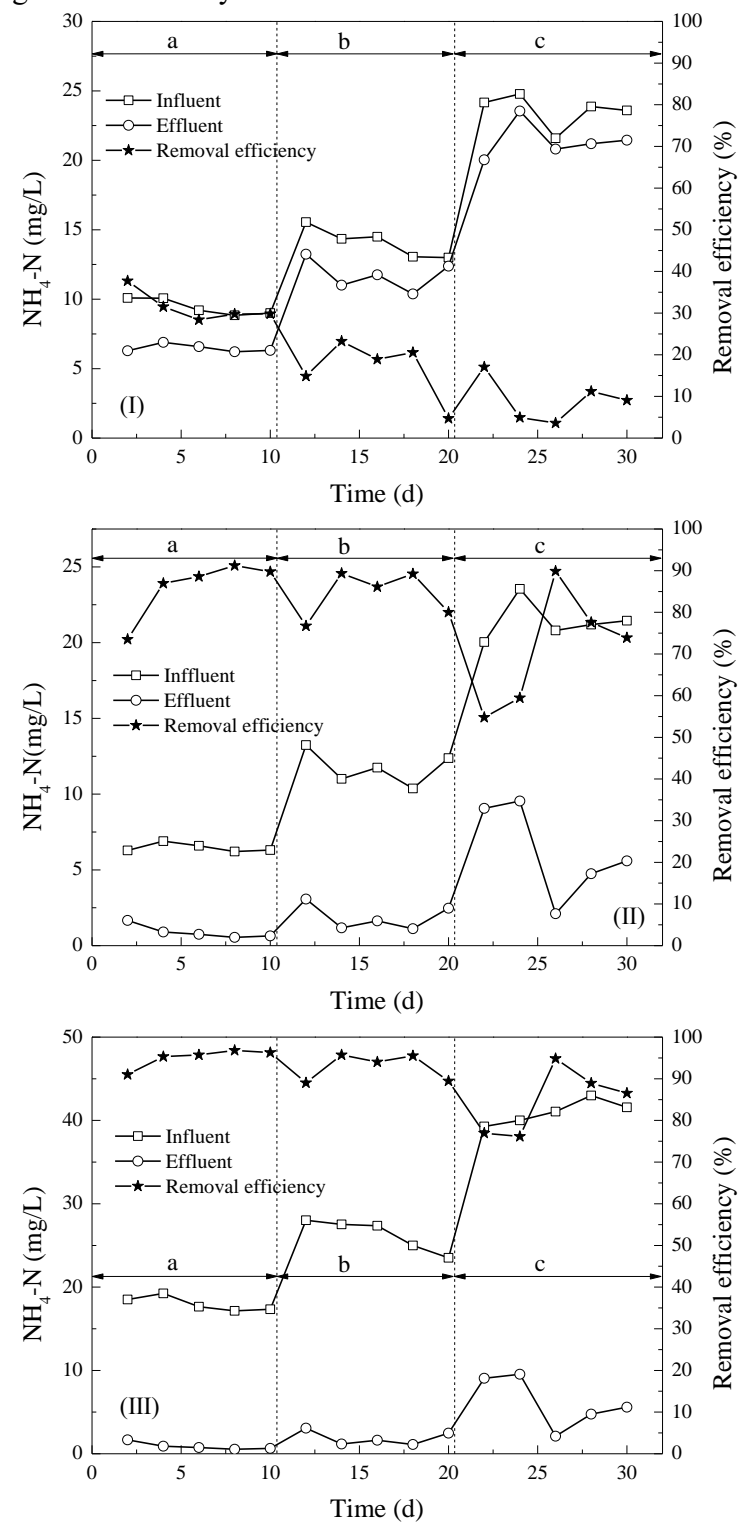

(a. $\mathrm{COD}_{\mathrm{Cr}}: \mathrm{N}: \mathrm{P}=350: 17.5: 3.5$; b. $\mathrm{COD}_{\mathrm{Cr}}: \mathrm{N}: \mathrm{P}=350: 25: 5$; . $\left.\mathrm{COD}_{\mathrm{Cr}}: \mathrm{N}: \mathrm{P}=350: 40: 5\right)$

Fig.2. Performance of (I) anoxic zone, (II) aerobic zone, (III) biological treatment system for ammonia-nitrogen removal
The removal effect of total phosphorus by biological reaction system was not ideal. As is shown in Fig.4, the removal efficiency of total phosphorus in the anoxic zone fluctuated around $25.02 \pm 14.10 \%$, which mainly consumed by microbial growth. The removal efficiency of total phosphorus in the aerobic zone gradually decreased from $21.29 \pm 4.17 \%$ to $6.93 \pm 1.12 \%$. The removal efficiency of total phosphorus in the bioreactor system also decreased from $59.24 \pm 7.48 \%$ to $39.69 \pm 8.75 \%$. and the final effluent total phosphorus was maintained at $3.10 \pm 0.42 \mathrm{mg} / \mathrm{L}$. The total phosphorus removal effect was poor, which was mainly because the reactor was not set up sludge reflux and sludge discharge frequency was low.
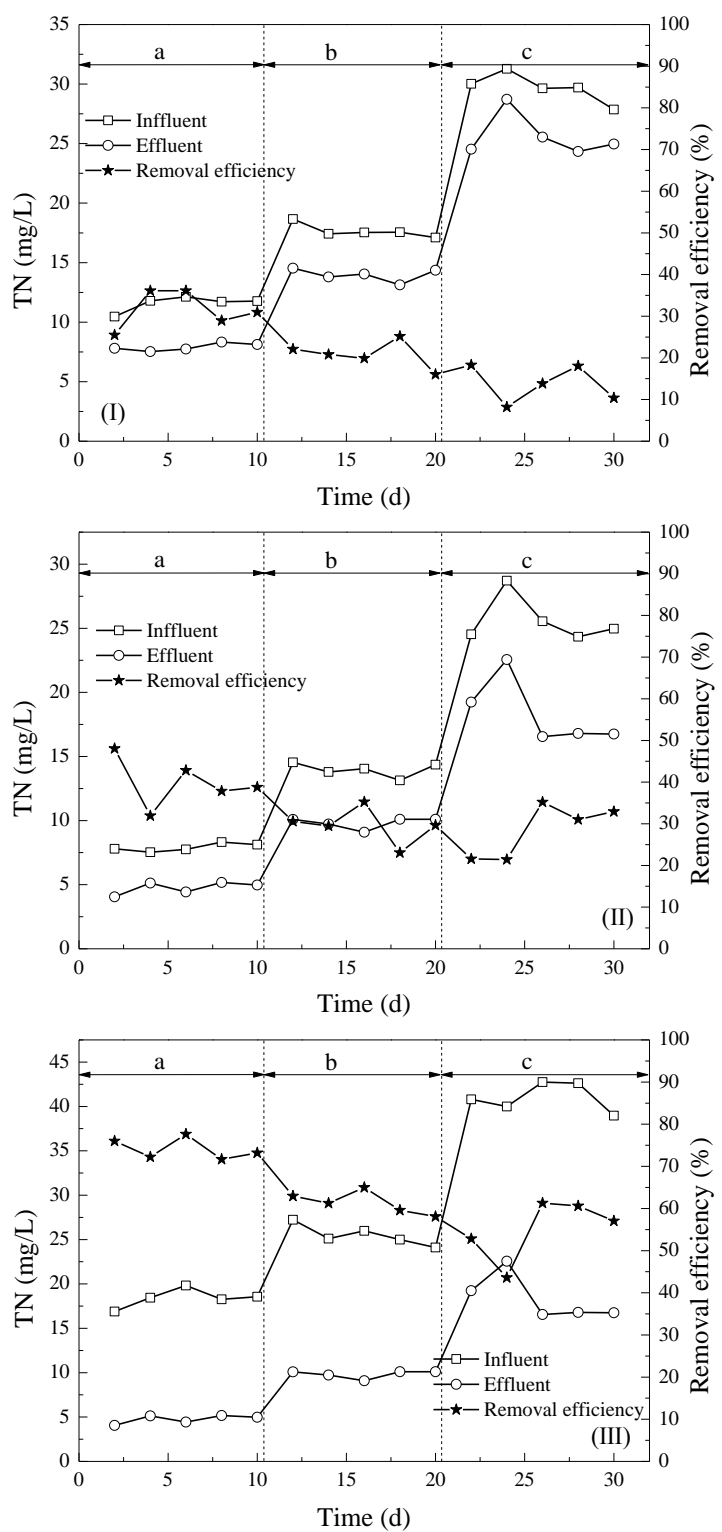

(a. $\mathrm{COD}_{\mathrm{Cr}}: \mathrm{N}: \mathrm{P}=350: 17.5: 3.5 ;$ b. $\mathrm{COD}_{\mathrm{Cr}}: \mathrm{N}: \mathrm{P}=350: 25: 5$; . $\mathrm{COD}_{\mathrm{Cr}}: \mathrm{N}: \mathrm{P}=350: 40: 5$ )

Fig.3. Performance of (I) anoxic zone, (II) aerobic zone, (III) biological treatment system for total nitrogen removal.

The removal effect of nitrate and nitrite in the anoxic zone during the start-up period is shown in Fig. 5. The anoxic zone showed good denitrification. With the running time went, the removal efficiency of nitrate in the anoxic zone gradually increased from $11.48 \pm 8.48 \%$ to $71.40 \pm 14.90 \%$. This was due 
to effluent nitrate concentration from the aerobic zone increased, which resulted in the influent nitrate concentration of anoxic zone increased. The effluent nitrate nitrogen concentration from the anoxic zone was relatively stable, which was maintained at $0.67 \pm 0.32 \mathrm{mg} / \mathrm{L}$. As for nitrite nitrogen, the influent nitrite concentration in the anoxic zone increased from $0.37 \pm 0.22 \mathrm{mg} / \mathrm{L}$ to $3.35 \pm 0.84 \mathrm{mg} / \mathrm{L}$, the effluent nitrite in the anoxic zone was maintained below 0.01 $\mathrm{mg} / \mathrm{L}$. The removal efficiency of nitrite in the anoxic zone was maintained at $98.31 \pm 2.24 \%$. It indicated that the anoxic zone had a good impact resistance to nitrate and nitrite.
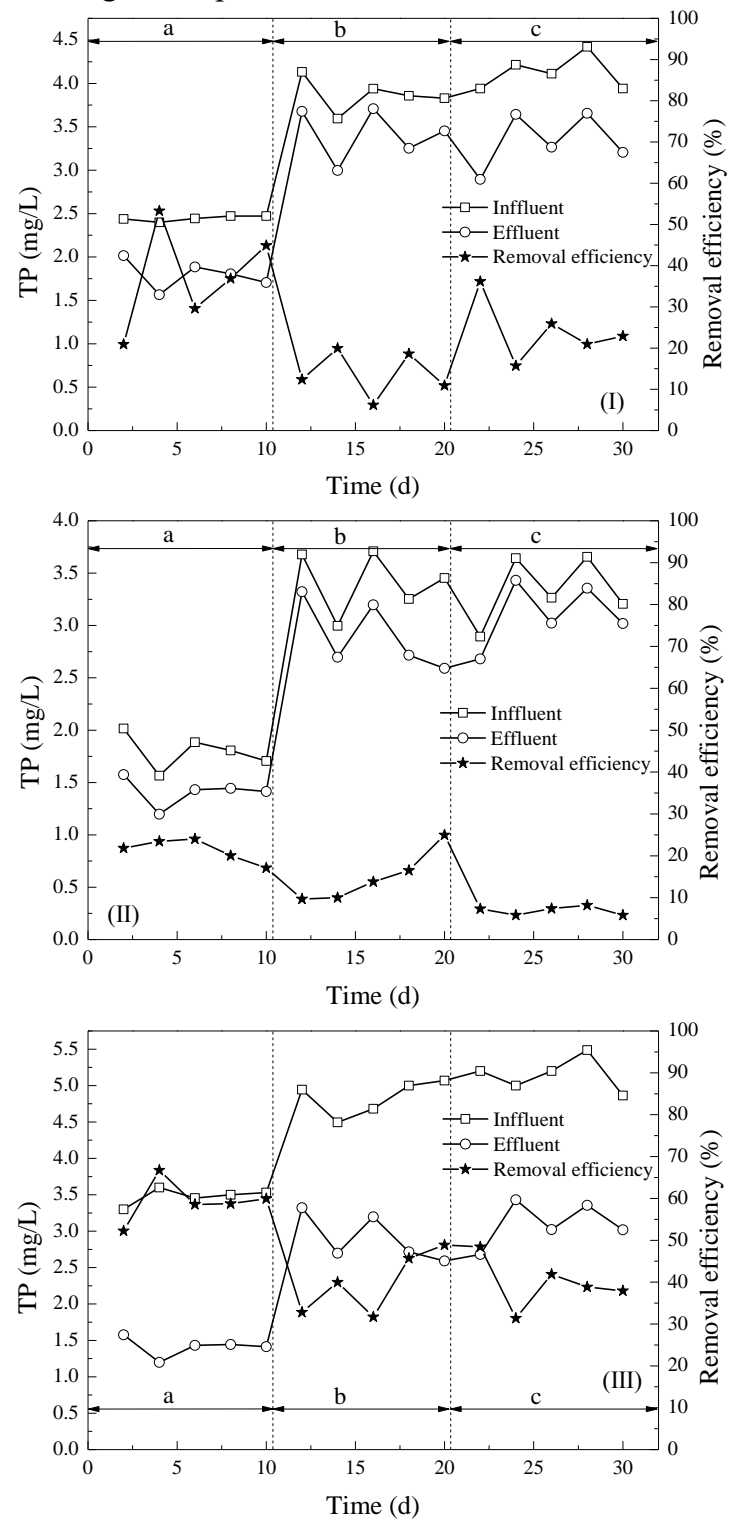

(a. $\mathrm{COD}_{\mathrm{Cr}}: \mathrm{N}: \mathrm{P}=350: 17.5: 3.5 ;$ b. $\mathrm{COD}_{\mathrm{Cr}}: \mathrm{N}: \mathrm{P}=350: 25: 5$; . $\left.\mathrm{COD}_{\mathrm{Cr}}: \mathrm{N}: \mathrm{P}=350: 40: 5\right)$

Fig.4. Performance of (I) anoxic zone, (II) aerobic zone, (III) biological treatment system for total phosphorus removal.
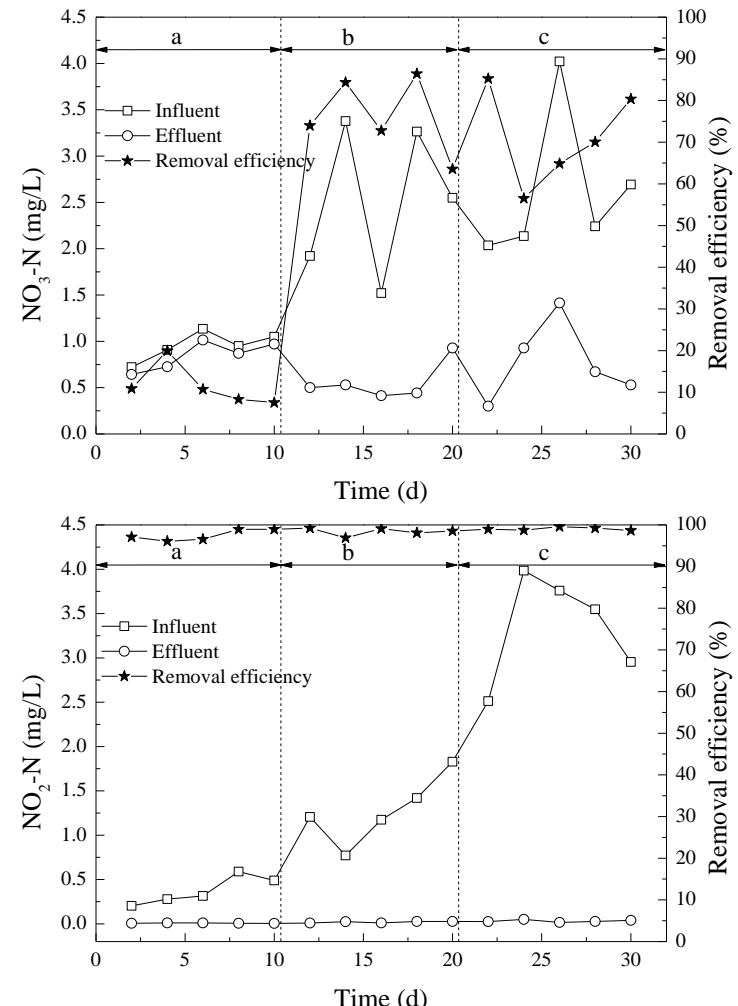

(a. $\mathrm{COD}_{\mathrm{Cr}}: \mathrm{N}: \mathrm{P}=350: 17.5: 3.5 ;$ b. $\mathrm{COD}_{\mathrm{Cr}}: \mathrm{N}: \mathrm{P}=350: 25: 5$; . CODCr:N:P=350:40:5)

Fig.5. Performance of anoxic zone for nitrate and nitrite removal

\section{Conclusions}

The aerobic zone successfully started up by employing the method of rapid draw-off sludge. The anoxic zone used the method of aerobic precoating of bio-medium combined with rapid draw-off sludge. With the increase of nitrogen and phosphorus loads, the biological reaction system had a stable removal effect on $\mathrm{COD}_{\mathrm{Cr}}$. The effluent $\mathrm{COD}_{\mathrm{Cr}}$ concentration was maintained at $27.40 \pm 12.48 \mathrm{mg} / \mathrm{L}$, and the average removal efficiency of $\mathrm{COD}_{\mathrm{Cr}}$ was $92.32 \%$. The removal effect of ammonia nitrogen decreased to some extent, but then gradually recovered, indicating that the reactor could withstand the ammonia nitrogen load. The final effluent ammonia nitrogen concentration was maintained at $4.15 \pm 2.04$ $\mathrm{mg} / \mathrm{L}$, with the removal efficiency of $90.12 \pm 4.74 \%$. The removal efficiency of total nitrogen decreased gradually. The removal efficiency of total nitrogen in the biological reaction system decreased from $74.14 \pm 3.51 \%$ to $55.07 \pm 11.47 \%$ with the increase of total nitrogen load. The removal efficiency of total phosphorus decreased slightly. The removal efficiency of total phosphorus decreased from $59.24 \pm 7.48 \%$ to $39.69 \pm 8.75 \%$, and the final effluent total phosphorus was maintained at $3.10 \pm 0.42 \mathrm{mg} / \mathrm{L}$. And the anoxic zone showed a stable and good denitrification effect. It is resulted that the biological reaction system was quickly started up and the $\mathrm{A} / \mathrm{O}$-mixed filler carrier system had a good removal effect on organic pollutants for simulated domestic sewage in the startup period. This study combined biofilm method and $\mathrm{A} / \mathrm{O}$ process reasonably to form the biological treatment system, which provided a new method for improving the quality and efficiency of urban sewage treatment plants. 
This research was supported by the National Natural Science Foundation of China (No. 51308362).

\section{References}

1. S. Wang, Y. Peng, Natural zeolites as effective adsorbents in water and wastewater treatment, Chem Eng J, 156 (2010) 11-24.

2. K. Suzuki, Y. Tanaka, K. Kuroda, H. Dai, Y. Fukumoto, T. Yasuda, M. Waki, Removal and recovery of phosphorous from swine wastewater by demonstration crystallization reactor and struvite accumulation device, Bioresour Technol, 98 (2007) 1573-1578.

3. X. Yan, C. Zhu, B. Huang, Q. Yan, G. Zhang, Enhanced nitrogen removal from electroplating tail wastewater through two-staged anoxic-oxic (A/O) process, Bioresour Technol, 247 (2018) 157-164.

4. C.P. Gerba, W.Q. Betancourt, M. Kitajima, C.M. Rock, Reducing uncertainty in estimating virus reduction by advanced water treatment processes, Water Res, 133 (2018) 282-288.

5. P. Babatsouli, I. Palogos, E. Michalodimitraki, C. Costa, N. Kalogerakis, Evaluation of a MBR Pilot
Treating Industrial Wastewater with a High COD/N Ratio, J Chem Technol Biot, 90 (2015) 26-33.

6. H.J. Choi, A.H. Lee, S.M. Lee, Comparison between a moving bed bioreactor and a fixed bed bioreactor for biological phosphate removal and denitrification, Water Sci Technol, 65 (2012) 1834.

7. M. Hultberg, L.E. Olsson, G. Birgersson, S. Gustafsson, B. Sievertsson, Microalgal growth in municipal wastewater treated in an anaerobic moving bed biofilm reactor, Bioresour Technol, 207 (2016) 19-23.

8. D.H. Shin, W.S. Shin, Y.H. Kim, M.H. Han, S.J. Choi, Application of a combined process of moving-bed biofilm reactor (MBBR) and chemical coagulation for dyeing wastewater treatment, Water Sci Technol, 54 (2006) 181-189.

9. N. Kaindl, Upgrading of an activated sludge wastewater treatment plant by adding a moving bed biofilm reactor as pre-treatment and ozonation followed by biofiltration for enhanced COD reduction: design and operation experience, Water Sci Technol, 62 (2010) 2710-2719. 